\title{
'Just a Quack Who Can Cure Cancer': John Braund, and Regulating Cancer Treatment in New South Wales, Australia
}

\author{
LAURA L. DAWES* \\ 21 Clianthus Street, O’Connor, ACT 2602, Australia
}

\begin{abstract}
In 1948 the New South Wales government instituted an inquiry into the claims of John Braund - a 78-year-old self-described 'quack' - that his secret treatment had cured 317 cancer sufferers. The 'Braund controversy', as it became known, was one of Australia's most prominent cases of medical fraud. This paper examines that controversy and its effects on cancer philanthropy, medical research, and especially on legislation regulating treatment providers up to the present. With the Braund controversy in mind, the New South Wales (NSW) parliament struggled to develop legislation that would protect patients and punish quacks but also allow for serendipitous, unorthodox discoveries. Recent decades saw new elements added to this calculus - allowing a wide-ranging health marketplace, and allowing patients to choose their therapies. This paper argues that the particular body of law legislatures used in regulating cancer treatment and how regulations were framed reflected the changing context of healthcare and illustrates the calculus legislatures have undertaken in regulating the health marketplace, variously factoring in public safety, serendipitous discovery, the authority of orthodox medicine, patient choice, and economic opportunity.
\end{abstract}

Keywords: John Braund, Cancer Treatment Regulation and Legislation, New South Wales, Quackery, Medical Fraud

It started with an article in the Sun in 1947. The newspaper - cautiously warning readers not to accept any claims until proven - suggested that its reporter had found medical gold: 'this man says he can cure cancer'. ${ }^{1}$ The man in question was John Braund, a 78-year-old self-described 'quack', living in a villa in suburban Sydney, who said he had treated 318 cancer patients, and cured all but one of them. The Sun's journalist had also interviewed an anonymous 'cancer specialist' who said he was baffled by Braund's successes. Braund

* Email address for correspondence: 1dawes@ post.harvard.edu With thanks to Professor Irene Styles and Russell Miles for their editorial suggestions.

${ }^{1}$ G. H. Johnston, 'This Man Says He Can Cure Cancer', Sun, 2, December (1947), 17. 
kept the details of his method secret, but revealed that he gave no medicine and 'use[d] no knife' to achieve his spectacular cures.

The 'Braund controversy', as the saga provoked by the Sun's coverage came to be known, was one of Australia's most prominent cases of medical fraud, sharing features with the growing number of scholars' accounts of medical charlatans in other countries and deserves historical investigation from that aspect alone. ${ }^{2}$ But the controversy also had repercussions beyond its immediate interest. For one, it initiated a cascade of legislation in New South Wales (NSW) regulating cancer treatment. After describing the Braund controversy in the first half of the paper, I then examine the nature of those legislative changes, and the reasoning behind them. Parliamentary discussions show that legislatures grappled with balancing competing priorities in the treatment of cancer, but that those priorities were changed over the ensuing sixty years. When the NSW parliament first debated legislation restricting cancer treatment, their concern was to protect the public while allowing the possibility that unorthodox approaches might happen upon a cure. I refer to this as 'the Sister Kenny problem'. (Sister Elizabeth Kenny - then, and now, an 'Australian icon' - was a self-taught nurse who developed a treatment for polio and whose example was much in the minds of the NSW legislature.) In contrast, the idea that laws ought to balance protecting the public against a patient's right to chose his or her therapy, or with the economic desirability of having a vibrant health sector, is a recent framing of the issue. The Braund controversy and its legislative aftermath, therefore, helps illustrate the calculus that legislatures have undertaken in regulating the health marketplace, variously factoring in public safety, serendipitous discovery, the authority of orthodox medicine, public choice, and economic opportunity.

For another, the Braund controversy speaks to the issue of professionalisation in medicine - that process of developing specialised group knowledge and association, self-regulation, and control. Legislation that restricts provision of cancer treatment to registered practitioners only satisfies the requirements of Abbott's 'professionalisation event', meaning a milestone achievement in the course of professionalisation. ${ }^{3}$ But contrary to the usual framing of professionalisation as a process prompted and shepherded by the profession itself, the Braund controversy shows that, in rarer instances, the professionalisation of medicine can be achieved without the medical profession's

\footnotetext{
2 There have been notable scholarly studies of quackery and specifically cancer quackery in the US, UK and Canada. For example, D. Cantor, 'Cancer, Quackery and the Vernacular Meanings of Hope in 1950s America', Journal of the History of Medicine and Allied Sciences, 61 (2006), 324-68; B. Clow, Negotiating Disease: Power and Cancer Care, 1900-1950 (Montreal: McGill Queens University Press, 2001); L.R. Croft, 'Edmund Gosse and The "New and Fantastic Cure" For Breast Cancer', Medical History, 38 (1994), 143-59; M. Fishbein, 'History of Cancer Quackery', Perspectives in Biology and Medicine, 8 (1965), 139-66; C. Hayter, An Element of Hope (New Baskerville: McGill-Queen's University Press, 2005); E.S. Juhnke, Quacks and Crusaders (Lawrence, KS: University Press of Kansas, 2002); I.J. Lerner, 'The Whys of Cancer Quackery', Cancer, 53 (1984), 815-19; J.H. Young and R.E. McFadyen, 'The Koch Cancer Treatment', Journal of the History of Medicine and Allied Sciences, 53 (1998), 254-84; J.H. Young, The Toadstool Millionaires (Princeton, New Jersey: Princeton University Press, 1961); J.H. Young, The Medical Messiahs (Princeton, NJ: Princeton University Press, 1992); J.H. Young, American Health Quackery (Princeton, NJ: Princeton University Press, 1992).

${ }^{3}$ A. Abbott, 'The Order of Professionalization', Work and Occupations, 18 (1991), 355-84.
} 
involvement. ${ }^{4}$ Professionalisation can be the by-product of other organisations' and individual's actions.

\section{Cancer in Mid-Century Australia}

In the mid-twentieth century, cancer was widely recognised as 'a dread disease' and, in 1947, was third after pneumonia and heart disease in the leading causes of death in Australia. However, the condition appears to have loomed even larger in national fears, as it was erroneously reported during the Braund controversy as killing more Australians than any other condition. ${ }^{5}$ It was a frightening disease because it seemed to strike without reason and because treatments available at the time - surgery, radium, and X-rays - were painful, uncertain, and sometimes significantly scarring. James Patterson in his history of cancer has noted how these aspects of cancer - unpredictability and distressing treatment - gave the disease its 'dreadful' reputation. ${ }^{6}$

Moreover, in Australia, treatment and diagnostic improvements had not checked rising mortality rates from cancer since the nineteenth century. Officially compiled statistics held that mortality from all types of cancer had increased by a factor of four from 1879 when the first data on cancer mortality in Australia were collected. ${ }^{7}$

Some states (but not NSW) had established anti-cancer charitable organisations. Queensland's Cancer Trust, established in 1929, was the most vocal of all the existing cancer charities, having been founded with an educational intent. The trust undertook to educate the public in that state with leaflets, lectures, railways posters, and press propaganda, covering early signs and symptoms and 'draw[ing] public attention to the need for diagnosis and early treatment'. ${ }^{8}$ In New South Wales, however, cancer control activities were channelled through the University of Sydney's Cancer Research Committee, which coordinated radium supplies issued by the Commonwealth Government to hospital clinics and also trained physicians in cancer diagnosis and treatment. ${ }^{9}$ Despite

\footnotetext{
${ }^{4}$ In regards to the framing of professionalisation, see the two basic models of professionalisation - that proposed by Talcott Parsons in his 1939 essay 'The Professions and Social Structure' where he described professionalisation as a process characterised by self-regulation, technical expertise, disinterestedness, and association among professionals - and the criticisms of the Talcott model, informed by sociology and by Foucauldianism which posited that the driving force of professionalisation was to create and consolidate power. See T. Parsons, 'The professions and social structure', in T. Parsons, Essays in Sociological Theory (New York: Free Press, 1954), 34-49; J.C. Burnham, 'How the Concept of Profession Evolved in the Work of Historians of Medicine', Bulletin of the History of Medicine, 70 (1996), 1-24; G.L. Geison, Professions and Professional Ideologies in America (Chapel Hill, NC: University of North Carolina Press, 1983), 3-11; J. Goldstein, 'Foucault Among the Sociologists: The "Disciplines" and the History of the Professions', History and Theory, 23 (1984), 170-92; W.G. Rothstein, 'Professions in Process', Bulletin of the History of Medicine, 70 (1996), 691-8; I. Waddington, 'The Movement Towards the Professionalisation of Medicine', British Medical Journal, 301 (1990), 688-90.

${ }^{5}$ Eg. 'Braund Steps Behind His Wire Curtain', Daily Mirror, 3 February 1948, 1.

6 J. T. Patterson, The Dread Disease (Cambridge, MA: Harvard University Press, 1987).

${ }^{7}$ Report of the Ninth Australian Cancer Conference (Canberra: Commonwealth of Australia, 1938).

${ }^{8}$ E. R. Pike, 'Secretary of the Queensland cancer trust', in Report of the First Conference of the Cancer Organizations of Australia (Canberra: HJ Green, 1930), 9. Also B.L.W. Clarke, 'Foundation of Cancer Treatment in Queensland', Medical Journal of Australia, 2 (1969), 1271-4.

${ }^{9}$ There are a number of similarities between the organisation of cancer control in Australia and that in Canada, especially in relation to radium treatment. Canada devised its services after a receiving a report on the Australian model. See for example, Hayter, op. cit. (note 2); C. Hayter, 'Historical Origins of Current Problems in Cancer Control', Canadian Medical Association Journal, 158 (1998), 1735-40. For other international comparisons, see L. Breslow, A History of Cancer Control in the United States, 1946-1971, Prepared by the History of Cancer
} 
the urging of cancer organisations represented at the national Cancer Conferences (held yearly from 1930), the university's Cancer Research Committee did not have a public education thrust - its focus was on treatment, professional education, and research - and nor did New South Wales have a charitable cancer organisation. ${ }^{10}$ (It is possible that the committee's location within the university and its association with the professional values and standards of recognition there made the committee less inclined to spend money on public education. But even when NSW did establish a cancer charity in 1955, the attitude of that body was that public education was "one of the "less spectacular" aspects of a cancer campaign'.) ${ }^{11}$ Moreover, in the late 1930s the Cancer Research Committee had gone through a much-publicised organisational meltdown, replete with the suicide of one of its directors under accusations of financial mismanagement. ${ }^{12}$ In the 1940 s cancer control in NSW comprised a small remnant group at the university doing basic cancer biology research with three hospitals, all in the Sydney metropolitan area, offering cancer treatment. Rural NSW, where Braund first worked, was particularly poorly served, with just two regional clinics - neither particularly far from Sydney - offering skin cancer therapy. Cancer control in NSW at the time of the Braund controversy was therefore focussed on cancer research and treatment, with little attention given to, or coordination with, legislation, public policy and information, and cancer detection. Media coverage conveyed to the population a sense of a growing threat of cancer, but officialdom did not communicate to the public that it had the matter in hand. ${ }^{13}$ The field was ripe for unorthodox approaches.

\section{Context of the Braund Controversy: Legal Circumstances and the Position of the Medical Profession}

Two highly publicised cases of cancer quackery occurred shortly before the Braund controversy. The first was in Queensland in 1932, when a man named George Roberts

Control Project, UCLA School of Public Health (Washington, D.C.: Department of Health, Education, and Welfare, 1977); D. Cantor, 'Cancer Control and Prevention in the Twentieth Century', Bulletin of the History of Medicine, 81 (2007), 1-38.

${ }^{10}$ Eg. Report of the Seventh Australian Cancer Conference (Canberra: Commonwealth of Australia, 1936), 26-7; Report of the Eighth Australian Cancer Conference (Canberra: Commonwealth of Australia, 1937), 22-3.

${ }^{11}$ NSW State Cancer Council, Annual Report of the NSW State Cancer Council (Sydney: A.H. Pettifer, 1955), 11. See also New South Wales State Cancer Council, Cancer: Early Symptoms and Signs, (Sydney: NSW State Cancer Council, 195?); New South Wales State Cancer Council, Report for Lay Readers on the Projected Cancer Research Programme (Sydney: NSW State Cancer Council, 1955); New South Wales State Cancer Council, Research Report 1955 (Woolloomooloo: Benchmark Press, 1996).

12 History of the Cancer Research Council (CRC) is given in W.M. Goss and R.X. McGee, Under the Radar (London: Springer, 2010); H. Hamersley, 'Cancer, physics and society', in R.W. Home (ed.), Australian Science in the Making (Cambridge: Cambridge University Press, 1991), 197-219. See also H.G. Chapman, 'The Dream that Came True', Journal of the Cancer Research Committee, 1 (1929), 5-16; J.H.L. Cumpston, 'Facts About Cancer in Australia', Journal of the Cancer Research Committee, 1 (1929), 27-36; M.L. Holmes, Review of Cancer Organisation in Australia and the Position Regarding Facilities Provided for Investigation, Examination and Treatment (Canberra: Commonwealth Department of Health, 1935); F.A. Maguire, 'A Review of the Treatment of Cancer since the Inauguration of the University of Sydney Cancer Research Fund', Journal of the Cancer Research Committee, 8 (1938), 78-81; F.P. Sandes, 'The Cancer Campaign', Journal of the Cancer Research Committee, 1 (1929), 17-26; 'Cancer Research Fund', Sydney Morning Herald, 27 July 1934, 8; O.U. Vonwiller, 'Cancer Research at the University of Sydney', Journal of the Cancer Research Committee, 8 (1938), $52-73$.

${ }^{13}$ Eg. 'Cancer Problem', Sydney Morning Herald, 6 May 1936, 14; 'Cancer's Toll: Increased Mortality. Latest Figures', Sydney Morning Herald, 14 April 1937, 15; 'Fight Against Cancer', Sydney Morning Herald, 18 February 1939, 13; 'Cancer Statistics Not Reliable', Sydney Morning Herald, 26 February 1941, 4. 
claimed a cancer would disappear a month after injection with his secret formula. ${ }^{14}$ Roberts set up a registered company to sell his services. At Robert's request, a governmentappointed committee investigated his methods and sent three cancer volunteers to him for treatment. As it transpired, that involved injecting a strong and very painful acid into the tumour. Tragically, under Roberts' care, all three volunteer patients worsened, and one died shortly before the inquiry reported that Roberts was a 'sham and a fraud' and his treatment was both painful and ineffective. In the other instance, a Dr Ulric Williams in New Zealand was offering patients the Koch-Baker cure - a treatment of supposedly cancer-killing injections popular in the United States (US) in the 1920s and 1930s (and which, it should be said, had already been discredited in that country). ${ }^{15}$ Government investigation of that treatment determined that Williams was injecting a 'powerful sclerotic agent' (again, a strong acid) into his patients' tumours, but argued that 'crude destruction [of body tissue]... is very far from a cure' ${ }^{16}$ In neither case was legal action taken against the purveyors of these treatments.

Unorthodox or even fraudulent cancer treatment practices were not, however, totally immune from legal scrutiny. In extreme cases, criminal statues might come to bear: in an 1892 case, father and son Sam and Thomas Hood were found guilty of manslaughter and imprisoned for treating a woman, Rebecca Cohen, for throat and chin cancer using caustic poultices. Cohen died under the Hood's care. The judge held that the Hoods had continued treating her even as she deteriorated out of 'greed, unblushing impudence, gross ignorance, systematic falsehood, and callous indifference to human life and suffering'. ${ }^{17}$ At that time - 1892 - NSW did not have any legislation that would have treated the Hoods' transgressions as infringing medical practice regulations.

After a 1900 amendment to the 1898 Medical Practitioners' Act, a far more common offence which could apply to practitioners offering to treat cancer was one of 'holding out' - claiming or implying one was a doctor or surgeon. That infringement could be punished by a fine. In fact, Braund himself had been charged and fined $£ 60$ for two breaches of this provision in 1945 when he advertised himself as a 'doctor' and 'manipulative surgeon'. This experience, he later claimed, had cured him of his 'ignorance of the law'. ${ }^{18}$ Later amendments to the Medical Practitioners' Act furthered controls on unregistered practitioners' actions and advertising and increased fines for offences. But provided unregistered practitioners didn't use X-rays or radium, call themselves 'doctor', or advertise their medical services, they were otherwise unregulated. Braund's services were therefore not illegal by the Medical Practitioners' Act as at 1947, and nor was the Sun's coverage.

While Australia had had a history of vibrant engagement with empirical and household healing, it had not had the more heightened experience with quackery or with sectarian medicine that, say, had been the case in the US. ${ }^{19}$ Willis, in his history of medicine in

\footnotetext{
${ }^{14}$ Eg. 'Cancer Problem', Brisbane Courier, 13 October 1932, 3; 'Cancer Research', Brisbane Courier, 28 November 1932, 10; 'Cancer Test Proves a Failure', Brisbane Courier, 29 April 1933, 15.

15 M. Fishbein, 'History of Cancer Quackery', Perspectives in Biology and Medicine, 8 (1965), 139-66; Young and McFadyen, op. cit. (note 2).

16 'Report of the Committee of Inquiry into Claims of Cancer Cures by Mr J. Braund', Medical Journal of Australia, 1 (1948), 680-91.

17 'The Cancer Case', Sydney Morning Herald, 5 May 1892, 4.

18 'Braund Puts His Secret Formula in Safe Keeping', Sun, 8 February 1948, 5.

${ }^{19}$ Contrast, for example, N. Gevitz (ed.), Other Healers: Unorthodox Medicine in America (Baltimore, MD: Johns Hopkins University Press, 1988) and Young, The Toadstool Millionaires, op. cit. (note 2) with P. Martyr, Paradise of Quacks: An Alternative History of Medicine in Australia (Sydney: MacLeay Press, 2002). In spite
} 
Australia, argues that medical orthodoxy had fought in the 1910s to control the terms and conditions of the health market and, by the 1930s, had consolidated its dominance of healthcare in Australia. ${ }^{20}$ By the time of the Braund controversy, the medical profession in Australia had achieved professionalisation milestones of legislated restrictions on entry to the profession, an autonomous medical board, and control of work conditions through industrial action leading to the collapse of medical friendly societies. The subsequent events of the Braund case in the late 1940s shows that both the medical profession and the scientific approach to health had achieved sufficient status and regard to move government to protect the monopoly of the profession and the dominance of scientific medicine without medical organisations having to expend much (or, rather, any) effort.

Against this background, the Roberts and Williams cases and the fact that medical orthodoxy considered that the only effective cure for cancer was its early surgical removal made state legislatures increasingly wary of the extent to which unorthodox healers could attract seriously ill cancer patients and possibly dissuade them from going under 'the knife'. ${ }^{21}$

\section{Braund's Background and Treatment}

Braund's background is somewhat mysterious: during the controversy he avoided talking about his past and one reporter felt that he 'resented personal questions'. ${ }^{22}$ From electoral rolls and court records, it is apparent that Braund was born in Devon, England in 1867 and arrived in Australia in about $1891 .^{23}$ He moved around rural New South Wales - Berrigan, Lakemba, Bowral - holding various labouring jobs until he retired in about 1930. It was

of the misleading title, Martyr shows that Australia had a considerable engagement with household and, more recently, complementary and alternative medicine, but not quackery. Also B. Gandevia, 'A History of General Practice in Australia', Medical Journal of Australia, 2 (1972), 381-5; J.A. Gillespie, The Price of Health: Australian Governments and Medical Politics 1910-1960 (Cambridge: Cambridge University Press, 1991); J. Raftery, 'Keeping Healthy in Nineteenth-Century Australia', Health and History, 1 (1999), 274-97; R.S. Skirving, 'General Practice in Australia at the Dawn of the Century', Medical Journal of Australia, 1 (1951), 10-16; R. Travers and B. Gandevia (eds), The Irregulars: Some Examples of Complementary Medicine in Australia (Sydney: Royal Australian College of Surgeons, 1999); E. Willis, 'Doctoring in Australia: A View at the Bicentennial', Milbank Memorial Fund, 66 (1988), 167-81.

${ }^{20}$ Willis, ibid.

21 The more active state anti-cancer charities, such as the Queensland Cancer Trust (est. 1929) and, later, the Anti-Cancer Council of Victoria (est. 1937), sought to educate the public about signs and symptoms of cancer and encourage people to seek medical attention early. These bodies drew on the experience of cancer charities in the US and the UK with which they were affiliated. For example, a Victorian pamphlet urged readers that '[e]very case of cancer is an emergency.... The early application of proper treatment is very necessary for the cure of cancer. In some forms the opportunities for a favourable result decrease with each week's delay'. (7-8). The message was 'do not delay' - also the core message of cancer education in America - and, indeed, the Victorian association used the American Society for the Control of Cancer's materials as the basis for its publications. The Queensland Cancer Trust used print material from the British Empire Cancer Campaign but teamed it with more strident publicity than the British approach. Anti-Cancer Council of Victoria, What Every Adult Should Know About Cancer (Melbourne: Royal Australian College of Surgeons, 1940); Report, op. cit. (note 7). On the differing British and American approaches, see R.A. Aronowitz, 'Do Not Delay: Breast Cancer and Time, 1900-1970', Milbank Memorial Fund, 79 (2001), 355-86; E. Toon, “'Cancer as the General Population Knows It": Knowledge, Fear, and Lay Education in 1950s Britain', Bulletin of the History of Medicine, 81 (2007), 116-38.

22 'Quack Who Can Cure Cancer', West Australian, 7 February 1948, 2.

23 Attorney General and Justice, NSW Government, 2011, NSW Registry of Births, Deaths and Marriages, www.bmd.gov.au (accessed 11 March 2011); Australian Electoral Commission, 2011, Australian Electoral Rolls, 1903-1954, Ancestry.com, available online at http://search.ancestry.com.au/search/db.aspx?dbid=1207 (accessed 1 March 2011); ibid. 
after his retirement that he started treating people and describing himself as a 'hydropath'. It is not clear how Braund came by his approach to cancer treatment. In one account, he said that when he was twenty-three, he had been '[g]iven up by doctors as a hopeless cripple' but that he 'discover[ed] "key" truths about the blood circulatory system' and had cured himself. ${ }^{24} \mathrm{He}$ said that he was now applying the same insights to cancer.

Braund believed cancer was caused by a problem with bodily circulation (a 'blockage in the blood stream') and hence was amenable to massage, hydrotherapy, and blood 'detoxification'. ${ }^{25}$ Braund believed that it was critical for blood to be moved away from a person's heart and in order to achieve this would massage his patient's legs and feet, and use warm water foot baths. The more spectacular part of his treatment that news coverage dwelt on involved Braund injecting the patient with his secret formula. Sometimes he would inject the tumour itself or make a series of injections around the tumour, and sometimes, with internal cancers, he would inject a close or, in Braund's opinion, related part of the body, such as in one case of uterine cancer where Braund injected the woman's lower back. ${ }^{26}$ The formula's ingredients were secret, but Braund had, he said, told his wife Zillah what went into it and had written it down and put it 'somewhere safe' for posterity. ${ }^{27}$ The solution was milky in appearance, and had a distinctive smell, which one observer reckoned was ammonia. ${ }^{28}$ When Braund injected the tumour or around the tumour, the flesh would die and, after ten to twenty days, would slough off, leaving a 'purulent ulcer' at the injection site which Braund would bandage and leave to heal. ${ }^{29}$

\section{The Braund Controversy}

After its initial article on Braund, the Sun continued to stoke popular interest with followup articles and editorials. ${ }^{30}$ For the Sun - something of a rag - the Braund story was in keeping with its standard offerings of local celebrities, community events, and race meetings. Braund himself suggested that his method be tested by medical doctors and the Sun agreed that this should be done 'in the cause of humanity'. ${ }^{31}$ A few weeks after the newspaper ran its article, Braund, who had been treating at most one or two patients at any time, was treating up to thirty patients a day at his suburban home. People waited in his lounge, or on the front lawn to see him along with journalists, eager to see Braund in action. The story was widely circulated among a range of newspapers, although with a generally more sceptical tone than the Sun. ${ }^{32}$ In particular, the Daily Mirror (an afternoon newspaper which took a more worldly view of the news than the Sun's local personalinterest approach) sent a journalist to see Braund perform his treatment and concluded that, '[I]t is apparent that the old gentleman is suffering from hallucinations. He has no

24 'Quack Who Can Cure Cancer', op. cit. (note 22), 2.

25 'Special! Can John Braund Cure Cancer?' (Australia: Cinesound, 1948), 11 mins. Available online at http:// www.britishpathe.com/video/can-john-braund-cure-cancer/query/01122300 (accessed 1 March 2011).

${ }^{26}$ Report, op. cit. (note 16), 681.

27 'Braund Puts His Secret Formula', op. cit. (note 18), 5.

${ }^{28}$ Report, op. cit. (note 16), 689.

${ }^{29}$ Report, op. cit. (note 16), 681.

${ }^{30} \mathrm{Eg}$. Editorial, 'In the Cause of Humanity', Sun, 3 December 1947, 19; 'Cancer Expert Is Named', Sun, 2 February 1948, 1-2.

${ }^{31}$ Editorial, ibid., 19.

32 For example, 'Cancer Cure Claim; Premier Orders Inquiry', Sydney Morning Herald, 30 January 1948, 3; 'Braund and Cancer', Bulletin, 11 February 1948, 9; 'Mr Braund Wants Cancer Clinic Here', Argus, 3 February 1948, 3; 'Quack Who Can Cure Cancer', West Australian, 7 February 1948, 2; 'Trapper Satisfied with Braund', Canberra Times, 10 June 1948, 3. 
more ability to diagnose and cure cancer than Hottentots from the jungles of Africa' ${ }^{33}$ Somewhat cynically, therefore, the Daily Mirror offered to pay $£ 2,000$ to a hospital of Braund's choice if he could cure a patient certified as a cancer sufferer by British Medical Association doctors. And if Braund could, as he claimed, 'draw a cancer from the liver, through a patient's back' then the paper would increase their payment to $£ 5,000 .{ }^{34}$ Braund subsequently refused to speak to Daily Mirror reporters. He ordered them off his front lawn and shouted at them from behind his fly-screened front door. ${ }^{35}$

Braund was not, however, averse to all types of publicity. In February 1948 Cinesound, the Australian film and newsreel production company, produced a newsreel called Can John Braund Cure Cancer $?^{36}$ The reel screened in cinemas in a number of state capital cities. ${ }^{37}$ Multiple showings were needed each night to seat the interested audience. ${ }^{38}$ Although the narration cautioned that Braund's method had not been scientifically proven and that the film-maker's involvement was 'in the interests of truth - neither to support Mr Braund's claims nor to decry them', Cinesound nonetheless provided very positive coverage. ${ }^{39}$ Braund's patients gave testimonials claiming Braund was 'a very remarkable man' who had given them a 'new lease of life' and had done 'something no doctor could possibly do' in curing their cancer. ${ }^{40}$ The reel closed with comments from Dr Henry Brose, who had been the unnamed 'cancer expert' in the Sun's original piece. ${ }^{41}$ Brose said in the Cinesound reel that he had watched Braund's work for four years and that he knew 'too much about cancer to have any doubt that he [Braund] is able to cure at least some forms of it'. ${ }^{42}$ Brose was, however, a physicist, not a physician, although he was at the time working on the use of X-rays for cancer treatment. Brose had also set up clinics in Brisbane, Adelaide, and Sydney where he and his business partners offered the Koch injection treatment which quackery scholar James Harvey Young has written about. ${ }^{43}$ Brose worked closely with Dr Ulric Williams, the man who had been exposed in New Zealand for also using the discredited Koch-Baker injections. ${ }^{44}$ This aspect of Brose's previous engagement with cancer treatment was not mentioned in the reel.

Orthodox medicine kept an eye on the Braund saga as it unfolded, with descriptions of the events published in the news sections of medical journals, both in Australia and overseas. ${ }^{45}$ Interested doctors and concerned British Medical Association leaders attended showings of the Cinesound reel. The Royal Australian (later Australasian) College of

33 ‘£20,000 Cancer Offer Rejected by Braund’, Daily Mirror, 2 February 1948, 1.

34 Ibid..

35 'Braund Steps', op. cit. (note 5), 1.

36 'Special!', op. cit. (note 25).

${ }^{37}$ Eg. in Sydney, at the State, Lyceum, Victory, Capitol and Lyric theatres. In Brisbane, at the West Gabba Broadway, and in Melbourne at the Grosvenor, the Majestic and the Liberty theatres. 'Cinema listings', Sydney Morning Herald, 6 February 1948, 8; 'Cinema Listings', Courier-Mail, 4 March 1948, 4; 'Cinema Listings', Argus, 11 February 1948, 15.

38 'Braund Asks Hallstrom to Call Again', Daily Mirror, 5 February 1948, 5.

39 'Special!', op. cit. (note 25).

40 'Special!', op. cit. (note 25).

41 'Cancer Expert', op. cit. (note 30), 1-2.

42 'Special!', op. cit. (note 25).

43 Young and McFadyen, op. cit. (note 2).

44 'Injection Treatment for Cancer', The Advertiser, 7 September 1938, 27; 'Cancer Research Experiments', The Mercury, 14 October 1938, 6; H.L. Brose, 'To the Editor: Injection Therapy for Cancer', Sydney Morning Herald, 1 March 1939, 6.

45 W. C. Gibson, 'John Braund's Cure for Cancer', Canadian Medical Journal, 58 (1948), 625-6; 'Medical News', British Medical Journal, 1 (1948), 962; ‘Australasia: A Reputed Cancer Cure’, The Lancet, 251 (1948), 
Physicians also made a collection of newspaper cuttings tracking the saga. However, other than the British Medical Association (BMA) commenting to one newspaper that it would be amenable to unregistered practitioners being banned from advertising cancer treatments (which Braund had actually not done), organised medicine did not force any action on the issue. $^{46}$

By early February, Braund was receiving inquiries from cancer sufferers in other countries, including the United Kingdom (UK), the US, European countries, Canada, and Iraq. Four patients flew from Vancouver to be treated, including one woman whose husband sold their house to finance her trip. ${ }^{47}$

With rising public interest, and facing potential international embarrassment, NSW Premier, James McGirr, declared that he was taking up Braund's offer and would institute a commission of inquiry, as had been done before in the cases of cancer quackery in Queensland, New Zealand, and also Canada. ${ }^{48}$ McGirr chose the Director of Public Health, Doctor Emmanuel Morris, a long-term public health administrator and former member of the Army Medical Corps, to chair the committee. McGirr appointed to the committee a mixture of doctors recommended by the British Medical Association's NSW branch, and interested laymen, including Edward Hallstrom, a wealthy businessman who had made his considerable fortune inventing and selling the popular 'Silent Knight' refrigerator. Hallstrom was known in the community for his philanthropic work with, and trusteeship of, Sydney’s Taronga Zoo. He had offered Braund £20,000 to set up a cancer clinic in Sydney but, what with Braund's vacillations and having visited Braund at home and seen his methods - methods Hallstrom described as 'crude and disgustingly unhygienic' - he amended his offer to $£ 10,000$, conditional on doctors certifying three instances of cure. ${ }^{49}$ It was in recognition of this interest that McGirr appointed Hallstrom as one of the lay members of the committee.

Braund himself was also asked to nominate doctors and laymen to the committee and he suggested Dr Brose as one of his representatives. But soon after, Braund changed his mind about his offer to have doctors investigate his method. They were his 'enemies', he said, and were 'prejudice[d against him] without reason'. ${ }^{50}$ Why, he asked, should he be judged by doctors who themselves had been unable to cure cancer? ${ }^{51}$ This was not Braund's only sticking point with the committee. Morris, the chairman, decided that they would not send patients to Braund but would review his past cases instead. 'Names, names, names', Braund said. 'Everyone wants to know names. It's cures that count, not names. I don't keep records of patients... I know my people personally and remember all about them' ${ }^{52}$ For Braund's supporters - the Sun and Dr Brose - his vacillations on the inquiry were proving a strain. Braund should be excused, Brose said, because he was 'an old man

495; Braund Cancer Cure: Newspaper Cuttings, Royal Australasian College of Physicians - History of Medicine Library (Sydney, 1948).

46 'B.M.A. Wants Ban', Sydney Morning Herald, 15 April 1948, 2.

47 'Appeal to Braund', Sydney Morning Herald, 9 February 1948, 3; 'Canadians Go Home', Sydney Morning Herald, 15 April 1948, 3.

${ }^{48}$ Eg. 'Cancer Cure Claim', op. cit. (note 32).

${ }^{49}$ Eg. '£20,000’, op. cit. (note 33); 'Cancer Expert', op. cit. (note 30); 'Braund Steps', op. cit. (note 5); 'Mr Braund's Claims: $£ 20,000$ Offer Withdrawn’, Sydney Morning Herald, 3 February 1948, 3.

50 'Mr Braund's Claims', ibid., 3; 'Mr Braund', op. cit. (note 32), 3.

51 'Cancer Expert', op. cit. (note 30), 1.

52 'Mr Braund's Claims', op. cit. (note 49), 3. 
and inclined to be difficult. . . but that does not alter that fact that I' $m$ sure he has the answer to the problem of malignant growth'. 53

In gathering information about Braund's methods, the committee members went to see the Cinesound reel and, in March 1948, visited Braund's house to see him treat patients. They watched him do his massage, but Braund said that he couldn't show them the injection part of his cure because 'his patients had become frightened and departed' ${ }^{54}$ Nor would he tell the committee the secret formula for his injection. The chairman, Morris, pressed Dr Brose to tell them what he knew of the injection, suggesting that Brose had introduced Braund to the Koch and Baker injections. Brose denied that he had spoken to Braund about the Koch method and, moreover, that he had 'not the faintest idea' what Braund was injecting. ${ }^{55}$ (And indeed, given the length of time that Braund had been treating cancer patients, and the fact that his substance, unlike the Koch or Baker fluid, did not burn on contact, it seems unlikely that Brose had influenced Braund. ${ }^{56}$ )

Morris sent a slough - the dead piece of tissue Braund had removed from one of his patients - to the government's chemical analyst who suggested that Braund had injected the skin with alum (potassium aluminium sulphate). This chemical was used in the paper, leather and dying industries, but also in styptic pencils where its function as a blood coagulant made it useful for treating small shaving cuts. If Braund was indeed using alum - which he never admitted - then he was part of an extensive tradition of medical uses of alum, dating to ancient Egypt, where alum was used in cough medicines and, most notably, to treat swellings and to dry wounds. ${ }^{57}$ Alum continued to be part of materia medica into the early modern period and through until the present where it is occasionally used in surgery to stem bleeding. ${ }^{58}$ While the chemical evidence makes it likely that Braund was using alum, the notable ammoniac smell suggests that alum may not have been the only component.

The committee eventually received names and details of thirty-three people Braund claimed he had cured. Of these, the committee was able to find and interview only sixteen - the others were either dead, lived out of the state, or didn't want to be involved. (Some patients who declined to be involved in the investigation told the committee that Braund had indicated to them that he "was not agreeable to their being examined' ${ }^{59}$ ) Of the sixteen the committee examined and reviewed medical records for, the committee determined that some had not had cancer at all but rather an assortment of cysts or swellings that either Braund himself or medical practitioners had misdiagnosed. The committee also excluded cases of 'rodent ulcer' (basal cell carcinoma) which, because it doesn't normally

53 'Cancer Expert', op. cit. (note 30), 1-2.

54 'Report', op. cit. (note 16), 681.

55 'Report', op. cit. (note 16), 685.

56 The use of escharotics was common in unorthodox cancer treatment. See W.R. Dickie and N.C. Hughes, 'Caustic Pastes: Their Survival as Quack Cancer Remedies', British Journal of Plastic Surgery, 14 (1961), 97-109. An example of their use in Croft, op. cit. (note 2).

${ }^{57}$ L. Manniche, An Ancient Egyptian Herbal (London: University of Texas Press, 1999), 74, 80, 143, 150; J.R. Harris, Lexicographical Studies in Ancient Egyptian Minerals (Berlin: Akademie Verlag, 1961), 185-9. In Greek medicine, see J. Bostuck and H.T. Riley, 'Classics in Infectious Diseases: Excerpts from the Natural History of Pliny', Reviews of Infectious Diseases, 4 (1982), 1266-9: 1266.

58 In the early modern period, for example, an account on the uses of alum suggested that: ' ... dried or burnt alum as it is called is sometimes employed for drying foul ulcers and consuming proud flesh which it does with great mildness but it is said to have an inconvenience of leaving a hardness upon the part'. W. Lewis, An Experimental History of the Materia Medica or of the Natural and Artificial Substances Made Use of in Medicine (London: J. Johnson, 1784), 44.

59 'Report', op. cit. (note 16), 680. 
metastasise, the committee said "does not constitute the "cancer problem" as understood by the scientific world' ${ }^{60}$ The fact that the committee excluded rodent ulcer cases and failed to look in detail at cases which had been misdiagnosed as cancer by medical practitioners, suggests that the committee was, at least by this stage, bent on disproving and discrediting Braund's approach. Considering the former would have indicated Braund's method had partial merit, while the latter could have prompted moves to improve physician education. The committee also declined to consider why such a number of Braund's patients were 'firmly convinced' that they had cancer when they did not. (Recall that NSW did not have an anti-cancer organisation and, although the university's Cancer Research Committee had been urged to undertake public education activities, it had not done so.) The Braund controversy exposed a range of issues associated with cancer control in NSW and especially in rural areas - its public understanding, its diagnosis and treatment - but the committee steered away from any broader implications beyond Braund himself.

Moreover, beyond the committee's obvious frustration with Braund's uncooperative and crotchety manner, there were also class overtones to their judgement of him. Braund was working class, a former rural labourer, who spoke with a very broad, uncultured accent. His patients who had given testimonials in the Cinesound reel and also to the committee were from similar rural, working class backgrounds. In contrast, the committee members were all wealthy urbanites, mostly well-educated, middle-to-upper class. The committee chairman described Braund as 'ignorant' and lacking 'mental acumen' and told off the Rhodes-scholar Brose for ever having supported 'such a man' ${ }^{61}$ David Cantor's study of quack Harry Hoxsey in the US similarly reflects on the different affiliations of supporters and opponents of unorthodox treatments. ${ }^{62}$

Of the sixteen patients the committee was able to examine, the committee concluded that six had suffered from various cancers, including skin, breast, and oesophageal - and, indeed, were still suffering from cancer. Two of the cases, the committee held, had a reasonable prognosis should they seek conventional treatment, but four cases were serious: the committee described them as being 'very grave' with a 'limited expectation of life'. ${ }^{6}$ Braund had not cured them, the committee found, and his patients were getting worse under his treatment. The committee were harsh in their report to parliament in April:

The exploitation of Mr Braund's alleged cure amounts to an outstanding public mischief with international ramifications. It has lulled sufferers into a false sense of security, thereby preventing them from obtaining proper treatment at a curable stage of the disease, or, at least, affording them an opportunity to prolong their lives... Mr Braund is a fraud and a charlatan. ${ }^{64}$

Braund's international patients went home, with newspapers reporting their deaths in the following months. ${ }^{65}$ Edward Hallstrom instead gave the $£ 20,000$ to the Sydney Hospital to found a cancer clinic, and shortly afterwards increased his donation by another $£ 36,000 .{ }^{66}$ Although already noted for his philanthropic efforts for Taronga Zoo, Hallstrom's experience with the Braund controversy prompted him to add medical

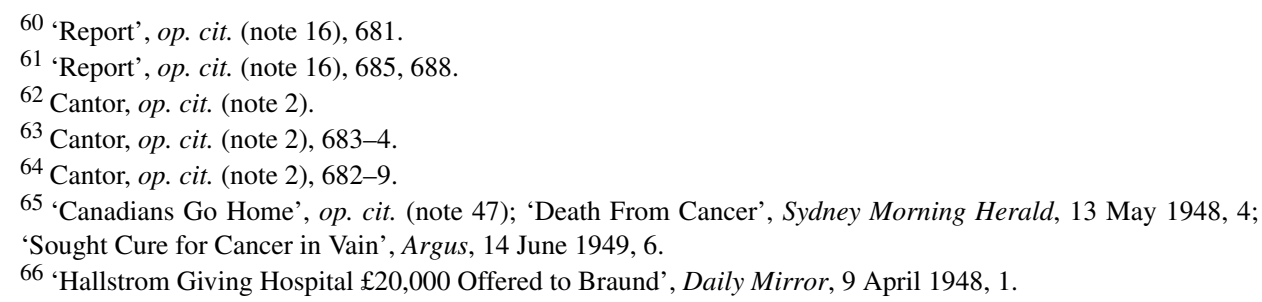


philanthropy to his interests, most especially supporting cancer treatment and research. ${ }^{67}$ From 1948 until his death in 1970, Hallstrom donated an estimated $£ 1.5$ million for cancer treatment and research (equivalent to about Au\$47 million in today's currency ) making him the country's foremost philanthropist for medical causes in the mid-twentieth century. ${ }^{68}$ He gave money and equipment to the Sydney, Royal Prince Alfred and Mater Hospitals, financed cancer clinics and sponsored an international exchange of doctors and surgeons. He was a founding member of the NSW State Cancer Council when it was established in 1955. ${ }^{69}$ By steering Hallstrom's philanthropy towards hospital practice and medical orthodoxy, the Braund affair contributed to establishing the cancer treatment infrastructure in hospitals and specialist clinics - a model that became, and has remained, the essential structure of cancer treatment efforts in NSW after the 1950s. ${ }^{70}$

Premier McGirr asked Braund to stop treating cancer patients. ${ }^{71}$ Contrary to popular belief about the quack growing rich off his gullible patients, Braund appears not to have profited from his business. He moved back to rural NSW, living in Walla Walla, but he did continue to quietly treat cancer patients. In 1954 a terminally ill young man died at Braund's house where Braund was allegedly treating him for stomach and leg cancer, and Braund was charged with unlawful possession of morphine. ${ }^{72}$ The charges were later dropped. Braund himself died the following year in 1955.

\section{Regulating Cancer Treatment}

The Braund controversy raised the question in the press and in parliament of whether legal measures were needed to curb mistakenly enthusiastic or downright fraudulent claims for cancer cures by non-medical people. ${ }^{73}$ There was some international precedent for this. For example, in 1939 Britain had enacted a Cancer Act that made it illegal for unregistered practitioners to advertise that they would treat cancer. Britain had several successful prosecutions under this legislation. ${ }^{74}$ In subsequent parliamentary discussions

67 'No. 1 Benefactor', Argus, 20 March 1952, 2.

${ }^{68}$ M. McGregor-Lowndes and W. Scaife, “'Of Droughts and Flooding Rains”: Philanthropy for Health and Medical Research', Medical Journal of Australia, 188 (2008), 631-2; M. Liffman, 'The Cultural and Social History of Philanthropy in Australia', Australian Philanthropy, 67 (2007), 4-5.

${ }^{69}$ Eg. 'Sydney Visits by Leading Cancer Men', Sydney Morning Herald, 25 September 1954, 3; 'Birthday Honours: Three Sydney Knights', Sydney Morning Herald, 5 June 1952, 1; 'No. 1 Benefactor', Argus, 20 March 1952, 2; B. Brownrigg, 'Doesn’t Know How Much Money He’s Given Away’, Barrier Miner, 22 October 1951, 4.

${ }^{70}$ Historians are increasingly appreciating the role that philanthropists can take in shaping the activities that they fund. The most obvious example of this is the extensive scholarship dealing with the Rockefeller foundation and its impact on medicine, economics, and the social sciences in the US. Eg. M. Bulmer and J. Bulmer, 'Philanthropy and Social Science in the 1920s: Beardsley Ruml and the Laura Spelman Rockefeller Memorial, 1922-29', Minerva, 19 (1981), 347-407; W.H. Schneider, Rockefeller Philanthropy and Modern Biomedicine (Bloomington, IN: Indiana University Press, 2002); D. Fisher, 'The Role of Philanthropic Foundations in the Reproduction and Production of Hegemony', Sociology, 17 (1983), 206-33.

71 'Braund to Stop Treatment of Cancer Patients', Sydney Morning Herald, 8 May 1948, 9.

72 'J. Braund Arrested on Drug Charge', Sydney Morning Herald, 30 October 1954, 4; 'Braund Drug Case Dismissed', Sydney Morning Herald, 24 November 1954, 10.

${ }^{73}$ Eg. 'Kelly Wants Stricter Medical Law', Sydney Morning Herald, 5 April 1948, 4; 'Move to Stop Cancer "Quackery”', Argus, 2 September 1949, 3; 'B.M.A. Wants Ban', op. cit. (note 46); 'Question on Braund', Sydney Morning Herald, 14 April 1948, 1; NSW Parliamentary Debates, Legislative Assembly (Sydney: Alfred Henry Pettifer, 1948), 4 December 1947; NSW Parliamentary Debates, Legislative Assembly (Sydney: Alfred Henry Pettifer, 1948), 13 April 1948.

74 Cancer Act 1939; Editorial, 'Medicine and the Law - Cancer Act Prosecution', The Lancet, 235 (1940), 708; Editorial, 'The Diagnosis and Treatment of Cancer', The Journal of the American Medical Association, 
in New South Wales over the next few decades, the Braund controversy was returned to with Braund specifically cited as the arch quack who had shown that cancer treatment needed regulating.

After the Department of Health investigated the Braund case and legal options, in 1956 the Minister for Health proposed a bill to amend the Medical Practitioners' Act. This proposal became known colloquially as the 'Quack's Bill'. The amendments set out a special class of serious diseases for which there would be penalties beyond the basic 'holding out' offences. Non-registered practitioners would be prohibited from offering to treat cancer, tuberculosis, polio, epilepsy, and diabetes, with the penalty being a fine of up to $£ 100$. These diseases were, in the opinion of the Department of Health and the Minister for Health, 'the more deadly diseases... which should be treated only by competent persons and that unskilled and unqualified persons should not be allowed to treat them'. ${ }^{75}$ These diseases were all those for which an orthodox treatment - sometimes a rather unpleasant treatment - existed, but no cure, and it is likely that this was the reason parliamentarians felt that patients suffering these particular diseases were in most need of defending from quacks. Braund - 'this humbug, this wicked impostor', in the words of one of the members addressing the bill - was 'the sort of thing that must be stamped out, if possible, by this measure' ${ }^{76}$

The Quack's Bill contained two new measures against cancer quackery. ${ }^{77}$ The first (section 41) was that unregistered health practitioners 'shall not give or perform any medical or surgical advice, service, attendance or operation in relation to' the specified dangerous diseases on penalty of a fine up to $£ 100 .{ }^{78}$ The second measure (section 42), directed at the supposed profitability of quackery, was that unlicensed practitioners would not be able to sue for unpaid fees, effectively putting all unlicensed health businesses beyond the protection of the law in respect of fees. One member did point out, however, that the second provision was unlikely to have a big impact because quackery was a generally cash practice. ${ }^{79}$ Certain unorthodox healing professions from among what would now be described as complementary and alternative medicine (CAM) were exempt from the act's provisions, however. Massage had been exempted in the 1938 version of the Medical Practice Act; the Quack's Bill added physiotherapy, chiropody and chiropractice to the exempted professions. During parliamentary debate, some members suggested that, given the institutional training demanded in the US, naturopaths be added to the exempt professions list, but this proposal was not taken up. ('I should like to check on these socalled [naturopathic] organisations in the United States before I accept them willynilly', said the Minister for Health. 'One hears of many queer organisations in that country'. ${ }^{80}$

The parliamentarians en bloc supported the bill's main intent to stamp out predatory quackery, but the legislature dwelt at length on the need to allow space for amateurs - or at least non-registered experimenters - to investigate deadly diseases and possibly find cures

117 (1941), 1905; Editorial, 'Medicine and the Law - Cancer Act Prosecution', The Lancet, 240 (1942), 56; R. Paterson, 'The Cancer Act', The Lancet, 240 (1942), 317-20; Editorial, 'Medicine and the Law - Another Cancer Act Prosecution', The Lancet, 241 (1943), 184.

${ }^{75}$ NSW Parliamentary Debates, Legislative Assembly (Sydney: Pettifer, 1957), 12 July 1956, 922, 1219.

76 Ibid., 925.

77 Ibid., 923.

78 Medical Practitioners (Amendment) Act No. 14, 1956, 3.

${ }^{79}$ NSW Parliamentary Debates, op. cit. (note 75), 924, 925. Compare with Anti-Cancer Council of Victoria, op. cit. (note 21), 15.

${ }^{80}$ NSW Parliamentary Debates, Legislative Assembly (Sydney: Pettifer, 1957), 26 July 1956, 1303. 
for them. It was, as Mr Treatt said, 'undeniable that not all pioneers of various methods of successful treatment have possessed a medical degree'. ${ }^{81}$ Members drew from history to cite notable contributors to science and medicine who had not been members of the certified mainstream - Herbert Barker (a 'bonesetter'), Inigo Jones (weather forecaster), Louis Pasteur, and, again and again, what they saw as the paradigm example: Australia's own Sister Elizabeth Kenny. 'How would this legislation affect Sister Kenny?'. ${ }^{2}$ Kenny, a self-taught nurse, had developed a successful, but unorthodox, treatment for infantile paralysis (polio). Although her approach had been rejected in Australia by a medical investigative committee, Kenny's success in America and later wider acceptance led to her being canonised on her death in 1952 as 'a great Australian'. ${ }^{83}$ The parliamentarians did not want the bill to restrict the hope that an unorthodox practitioner might serendipitously develop an effective treatment for serious disease. I refer to this dilemma as 'the Sister Kenny problem'. The legislature therefore saw the purpose of the cancer treatment legislation as having to do two things - stamp out the John Braunds of the world but still allow for the Sister Kennys.

Although the legislature did not at this time factor in a patient's choice as an element in their debate, they did not want the legislation to be seen as a favour to the medical profession. The Minister for Health was adamant that the Quack's Bill and its implied monopoly of orthodox medicine to treat cancer had not come about because of any lobbying efforts on the part of the British Medical Association. 'I want to give complete and emphatic denial to any Hon. member who may suggest that the Bill has been inspired by members of the British Medical Association', he said. ${ }^{84}$ Although the BMA did speak in favour of amending the legislation at the time of the Braund controversy, there is no evidence that they were a motive force behind the Quack's Bill. ${ }^{85}$ Rather, it seems as if measures had been under discussion since the Braund controversy, and continued to be kept in mind by ongoing cases of exploitative practices by unlicensed practitioners. The Quack's Bill was a 'professionalisation event' and resulted in restricting health practice to the benefit of orthodox medicine, but it was instituted by the legislature (not organised medicine) and not because the legislature wanted to shore up the medical profession, but because it wanted to be able to punish quacks like Braund.

The Quack's Bill was passed, but with the understanding that the bill 'was an experimental one' - a first attempt to legislatively separate the quacks from the valid but unorthodox healers. ${ }^{86}$ The Minister for Health was at pains to assure members that, although the bill might sound proscriptive, it was more about making punitive measures available, should they be needed. ${ }^{87}$ The implication was that the bill should be applied with discretion.

In subsequent years, the terms of the act restricting cancer treatment were variously amended, expanding the control of and heightening the punishments for selling cancer remedies and miracle products or offering to treat cancer. (The provisions dealing with other serious diseases besides cancer were not enlarged.) The greatest change to cancer treatment regulations occurred in 1967, prompted again by worries about the Sister

${ }^{81}$ NSW Parliamentary Debates, op. cit. (note 75), 925.

${ }^{82}$ NSW Parliamentary Debates, Legislative Assembly (Sydney: Pettifer, 1957), 25 July 1956, 1222.

83 'Sister Kenny is Dead', Sydney Morning Herald, 1 December 1952, 1.

${ }^{84}$ NSW Parliamentary Debates, op. cit. (note 83), 1221.

${ }^{85}$ Eg. 'B.M.A. Wants Ban', op. cit. (note 46), 2.

${ }^{86}$ NSW Parliamentary Debates, op. cit. (note 81), 1306.

${ }^{87}$ Eg. NSW Parliamentary Debates, op. cit. (note 83), 1220-2. 
Kenny problem. (And still in 1967 Braund was being remembered as the arch-quack the amendments were meant to deal with: '.. only a few years ago there was [a] gentleman at Beverly Hills [Braund] who claimed that by a method of injection he could cure cancer. [So]... we have no argument on the amendments to the Medical Practitioners' Act... ${ }^{88}$ ) The 1967 amendment empowered the now-established NSW State Cancer Council to form a Cancer Investigation Committee to look into claims of cures. This new mechanism seemed to allay the concerns of many of the parliamentary members about unorthodox approaches being excluded, but Mr Crabtree, member for Kohgarah, astutely noted that this measure did not actually solve the Sister Kenny problem. Kenny's polio treatment had been investigated by a commission with similar powers to that envisioned by the proposed Cancer Investigation Committee, but that commission had rejected her approach. The member concluded,

If an investigating committee had the powers in relation to the after-care of polio that he [the Minister for Health] proposed to give to the committee of the New South Wales State Cancer Council, Sister Kenny would have been for a long time a guest of Her Majesty in one of our State penitentiaries. ${ }^{89}$

The member had hit upon a historical problem in deciding on the merits of new and possibly revolutionary approaches: who decides? Medical experts, by virtue of their expert knowledge and professionalisation, were (and are) ironically both qualified and biased in being able to assess the merits of unorthodox healing approaches. ${ }^{90}$ (Canada also struggled with this issue when, for example as Barbara Clow notes in her study of cancer treatment in Canada, Ontario instituted a Commission for the Investigation of Cancer Remedies. ${ }^{91}$ ) While a committee of investigation formed from medical experts might be able to rule out the egregious quack, it may not be able to distinguish the revolutionary treatment. The legislature was looking to find a tool that would cleanly divide quackery from worthy alternatives to orthodoxy, but medical orthodoxy could not provide a scalpel that would make the 'correct' cut without fail.

When the Medical Practitioners' Act was entirely revised and reissued in 1992, the new Medical Practice Act retained a specific clause restricting unregistered practitioners from taking on patients with cancer (clause 109) with a further 'gab-bag' clause allowing the legislature to prescribe other serious diseases if it so desired. The two clauses used the same language and phrasing as the revisions prompted by the Braund controversy. However, the precise wording was amended to prohibit unregistered practitioners from claiming to 'cure' serious diseases (rather than the 1956 wording of 'treat'), and the later act also included a new clause prohibiting non-registered practitioners from implying that a product might 'alleviate' cancer. ${ }^{92}$

How successful were these legislative measures in addressing egregious cancer quackery? This is a difficult quality to assess, but if one uses the number of successful prosecutions under the relevant clauses as an indicator of the legislation's success, the conclusion must be that attempts to stamp out quackery using the Medical Practice Act have been a failure. I have found no evidence of any successful prosecution under either sections 41 or 42 of the Medical Practitioners Act 1936, nor under clauses 108 or 109 of

\footnotetext{
${ }^{88}$ NSW Parliamentary Debates, Legislative Assembly (Sydney: Blight, 1968), 12, 19 September 1967, 1343.

${ }^{89}$ Ibid., 1345.

${ }^{90}$ A similar issue is raised in M. Bishop, 'Should Doctors Be the Judges of Medical Orthodoxy? The Barker Case of 1920', Journal of the Royal Society of Medicine, 95 (2002), 41-5.

91 B. Clow, Negotiating Disease (Montreal: McGill Queens University Press, 2001).

92 Medical Practice Act 1992 (NSW), clauses 108, 109.
} 
the Medical Practice Act 1992. While it is certainly the case that databases of Australian legal decisions are not comprehensive, even at the time of the proposed 1967 amendment legislators noted that, 'as the law stands, it has been difficult to obtain convictions' ${ }^{93}$ This is curious, given that there were several successful prosecutions in Britain under that country's less comprehensive Cancer Act. There are different opinions as to why such prosecutions failed in New South Wales. One Member of Parliament (MP) who was closely interested in the issue said,

[u]nfortunately every case heard before a chamber magistrate of an unqualified person treating [cancer] has been dismissed because the magistrate has been of the opinion that these matters were not worth proceeding with and that no-one would take any notice if they were. ${ }^{94}$

And the Medical Board, who was the principle organisation bringing such cases said that,

[i]ts experience in seeking to enforce the provisions of section 108 and 109 has been singularly unsuccessful, even where serious consequences including death have resulted from the unregistered person's activities. This has been due to a number of factors, including evidentiary and burden of proof issues arising when matters are pursued in the local courts. ${ }^{95}$

Note that different parties ascribed to different reasons - lack of importance versus evidentiary requirements - why using the Medical Practitioners'/Practice Acts to regulate cancer treatment was a failure.

Indeed, in 1998, when NSW Health (the renamed state health department) reviewed the Medical Practice Act, it concluded that the clauses the Braund controversy had spawned ought to be removed on the grounds that,

'they do not provide more effective protections than those afforded by the broader regulatory environment and have shown to be unenforceable ${ }^{96}$

Moreover, the Australian health market was a different place in 1998 from when Braund was operating. Treatment modalities they may have been classified as 'unorthodox' in 1950, were now rechristened as 'complementary and alternative medicine (CAM)' - a change in name overlaying a complex shifting in attitudes, regulation, and doctor-patient relations. Other scholars have noted the increasing popular interest in CAM in Western countries in recent decades and Australia shared in this trend. (Baer argues that the increase in interest and use in Australia began in the late 1970s; a systematic review by Ernst and Cassileth suggests a later start date in the 1990s.) ${ }^{97}$ By the time of the health department's review, there was a substantial market for complementary and alternative medicine in Australia; but CAM had not replaced orthodox medicine by any means (most

93 NSW Parliamentary Debates, Legislative Council (Sydney: Blight, 1968), 10 October 1967, $2159-61$.

${ }^{94}$ NSW Parliamentary Debates, Legislative Council (Sydney, 2000), 29 June.

95 Joint Committee on the Health Care Complaints Commission, Inquiry into Regulating Unregistered Practitioners (NSW) (Sydney: HCCC, 1998), 79.

96 NSW Health, Final Report of the Review of the Medical Practice Act 1992 (NSW Health, 1998), v.

${ }^{97}$ In Australia, see for example, H.A. Baer, 'The Drive for Legitimation by Osteopathy and Chiropractic in Australia:', Complementary Health Practice Review, 11 (2006), 1-18; H.A. Baer, Complementary Medicine in Australia and New Zealand (Maleny: Verdant House, 2009); M. Weir, Complementary Medicine: Ethics and Law (Brisbane: Prometheus Publications, 2003); E. Ernst and B.R. Cassileth, 'The Prevalence of Complementary/Alternative Medicine in Cancer', Cancer, 83 (1998), 777-82; A.H. MacLennan, D.H. Wilson and A.W. Taylor, 'The Escalating Cost and Prevalence of Alternative Medicine', Preventive Medicine, 35 (2002), 166-73. For international comparison purposes, see P. Harris and R. Rees, 'The Prevalence of Complementary and Alternative Medicine Use Among the General Population', Complementary Therapies in Medicine, 8 (2000), 88-96; R.C. Kessler et al., 'Long-Term Trends in the Use of Complementary and Alternative Medical Therapies in the United States', Annals of Internal Medicine, 135 (2001), 262-68. 
users employed complementary, rather than alternative medicine, as part of a general health program), suggesting that it was in nobody's interest to severely limit unorthodox health practices. ${ }^{98}$ The Department had been petitioned by many CAM practitioners and their representative organisations, making the argument that their approaches, although not 'curative', could nevertheless be helpful to cancer patients. The Department concurred, saying it was against 'impeding the development of new and innovative services which may be of assistance to patients' and 'limiting consumer choice' ${ }^{99}$ Note that this was a different calculus than was involved in the Sister Kenny problem - the Health Department of the 1990s, it is implied, did not believe unorthodox medicine might serendipitously develop a cure for cancer, but rather that unorthodox medicine might offer other, noncurative benefits.

In light of the health department's recommendations and with the support of the Medical Board who felt it 'was inappropriate for it [the Board] to attempt to police the activities of unregistered persons offering to provide health care', in 2000, the New South Wales government repealed the sections of the Medical Practice Act which had restricted who could treat or claim to cure cancer. ${ }^{100}$ However, although the Medical Practice Act was silent on the matter, this did not mean that unregistered practitioners treating cancer were not covered under any form of law. With the heightened prevalence and popularity of alternative and complementary health in Australia, government also increasingly regarded unorthodox health practitioners as offering acceptable products and services as part of a wider health marketplace. For example, a discussion in 2003 in the Legislative Council on the use of complementary medicine in Australia referred to the 'complementary healthcare products sector' as 'an industry', peopled with 'retailers, manufacturers' and 'consumers'. ${ }^{101}$ This shift in attitude to unorthodox practitioners as managing businesses allowed governments to seek new areas of the law under which unorthodox practitioners' actions could be judged. In particular, unorthodox practitioners could be regarded as coming under the provisions of business regulations, namely the Commonwealth 1974 Trade Practices Act (for companies) and the parallel state Fair Trading Acts (for individuals) (in NSW, the Fair Trading Act 1987). ${ }^{102}$ Unregistered practitioners' claims as to their products and services could therefore be tested under clauses regarding 'misleading or deceptive conduct' and 'false representation'.

Ironically, in spite of the special, targeted clauses in the various Medical Practitioners'/Practice Acts that resulted from the Braund controversy, it has rather been cases brought against unregistered practitioners offering to treat or cure cancer under the Trade Practice and Fair Trading Acts which have been successful in the 2000s. In New South Wales, successful prosecutions have been brought by the Commission for Fair Trading (at a state level) and by the Australian Competition and Consumer Commission (at the federal level) against companies and individuals selling 'water purification drops', an electric 'positive ion mat', a 'radiation pulsation machine' and various tablets and

\footnotetext{
98 Ibid. Baer 2006, 2009; Weir; Ernst and Casileth; MacLennan, Wilson and Taylor.

${ }^{99}$ NSW Health, op. cit. (note 96), 79.

100 NSW Health, op. cit. (note 96), 79.

${ }^{101}$ NSW Parliamentary Debates, Legislative Council (Sydney, 2003), 21 May.

102 The actions of unregistered practitioners might also infringe the Poisons and Therapeutic Goods Act 1966 (NSW), the Therapeutic Goods Act 1989 (Commonwealth), the Food Act 1989 (NSW), the Crimes Act 1900 (NSW), and the Health Services Act 1997 (NSW). In practice, however, unregistered practitioners falsely claiming to cure cancer have been prosecuted under the Fair Trading and Trade Practices Acts.
} 
ointments, all making unsubstantiated claims to cure cancer, on penalty of closing down the business, and, in some cases, being fined. ${ }^{103}$

Although this route did result in successful prosecutions of unregistered practitioners falsely claiming to cure cancer, in the opinion of the NSW Health Department, 'the processes in the Fair Trading Act were difficult and slow and the regulator, the Department of Fair Trading, lacked appropriate expertise in investigating and addressing complaints' about cancer treatment. ${ }^{104}$ Although the Department and the Health Care Complaints Commission (HCCC, established in 1993 as a government organisation to act as a clearing house for healthcare complaints of all kinds, regardless of healing approach) received few complaints about CAM practitioners, it was of the opinion that this amount was not an accurate reflection of patients' satisfaction and that many people who might want to lodge a complaint against an unregistered practitioner may not, among other reasons, be aware of the mechanisms available for doing so. ${ }^{105}$ Moreover, the HCCC was only empowered to admonish the unregistered practitioner, not take action, while the ACCC and the Department of Fair Trading were thought to 'have their own priorities' and lacked the expertise to look at 'standards of care... preventing harm and... the clinical aspects of treatment'. 106

For those reasons, NSW Health and a parliamentary committee investigating regulations for unregistered health practitioners advised the Minister for Health, John Hatzistergos, to seek new legislation that would provide more options for investigating and punishing poor behaviour on the part of unregistered practitioners, including making claims to treat or cure cancer. This was essentially suggesting that the legislature revisit the old Braund-inspired clauses. But instead of putting such clauses back into the Medical Practice Act, the NSW legislature amended the Public Health Act to require that unregistered practitioners follow a code of conduct. The code would, in time, be developed in consultation with professional groups representing organised unorthodox medicine as well as the NSW Medical Board and the Office of Fair Trading. Practitioners who violated the code could be investigated and punished by the HCCC. The Commission would be given powers similar to those set out in the Fair Trading Act to issue public warnings - naming and shaming - and would be empowered to order an unregistered practitioner to stop treating patients. ${ }^{107}$ Breaching the HCCC's rulings would be a criminal offense. Although the amended Public Health Act allowing for a code of conduct was in place in 2006, it took two years to develop the

103 ACCC v Vassallo [2009] FCA 954 (20 August 2009); Commissioner for Fair Trading, Department of Commerce v Perrett [2007] NSWSC 1130 (12 October 2007); ACCC v Giraffe World Australia PTY LTD (No 2) FCA 1161 (26 August 1999). Other states have brought similar cases, for example, ACCC v Jones (No 5) FCA 49 (4 February 2011); ACCC v Nuera Health Pty Ltd (In liquidation) FCA 695 (9 May 2007); Noone, Director of Consumer Affairs Victoria v Operation Smile (Australia) and Ors (No 2) VSC 153 (19 April 2011); ACCC v Purple Harmony Plates PTY Ltd FCA 1062 (6 August 2011).

${ }^{104}$ L. O'Shannessy (Director Legal and Corporate Governance, NSW Department of Health), Personal correspondence, 23 March 2011, 2.

105 Joint Committee on the Health Care Complaints Commission, Report on Unregistered Health Practitioners: The Adequacy and Appropriateness of Current Mechanisms for Resolving Complaints (Sydney: NSW Parliament, Legislative Assembly, 1998), 15-28.

106 Ibid., 39-41. See also Joint Committee on the Health Care Complaints Commission, Review of the 1998 Report into Unregistered Health Practitioners: The Adequacy and Appropriateness of Current Mechanisms for Resolving Complaints (Sydney: NSW Parliament, Legislative Assembly, 2006), 20, 24.

107 Joint Committee on the Health Care Complaints Commission, Review of the 1998 Report into Unregistered Health Practitioners: The Adequacy and Appropriateness of Current Mechanisms for Resolving Complaints (Sydney: NSW Parliament, Legislative Assembly, 2006), 57. See also J. Hatzistergos, 'Getting Tough on Unregistered Health Practitioners', (Sydney: NSW Health, 2006). 
code which was issued in 2008. Clause five contained the requirement, mirroring the old clauses from the Medical Practice Act spawned by the Braund controversy and borrowing their language, that:

'Health practitioners [are] not to make claims to cure certain serious illnesses.

(1) A health practitioner must not hold himself or herself out as qualified, able or willing to cure cancer and other terminal illnesses'. ${ }^{108}$

The clause, however, contains a second subclause:

'(2) A health practitioner may make a claim as to his or her ability or willingness to treat or alleviate the symptoms of those illnesses if that claim can be substantiated'.

The two-clause structure to the cancer treatment restriction seeks to place boundaries on the seriousness of illnesses that CAM practitioners can treat (in the same way as the Quack's Bill did) but also allow for unorthodox discovery to be tested (in the way the 1967 amendments did). The Australian Health Ministers' Advisory Council calls the NSW system a 'negative licensing' regulatory regime because, while such practitioners don't have to pass any licensing or registration requirement, if they step out of bounds or behave badly, the legislation exists to take action against them. ${ }^{109}$

While the code of conduct's approach may seem a partial solution to the historical 'Sister Kenny problem' that plagued regulating cancer treatment, it has not found favour with all CAM and allied health groups covered by the legislation. On the one hand, the fact that the legislation does not require these practitioners to be licensed or registered is a plus from the 'Sister Kenny problem' perspective, allowing a bubbling health marketplace. But on the other hand, many groups (including occupational therapists, naturopaths, herbalists and radiographers) hoped that the legislation would require registration and so help them up the professionalisation ladder. ${ }^{110}$

\section{Conclusion}

The Braund controversy initiated a cascade of legislation in NSW seeking to regulate who could offer to treat or cure cancer. The case also illustrated what would become enduring themes in the legal approach to cancer treatment regulation. Legislatures struggled to balance protecting patients and punishing quacks against allowing serendipitous discoveries from beyond the boundaries of orthodox medicine. I have called this dilemma the 'Sister Kenny problem' since it was the case of Sister Kenny and her polio treatment that legislatures kept returning to as the type of unorthodox endeavour they would not like their laws to stamp out. In more recent years since the 1990s, the legislature has added another element to its considerations - allowing for a vibrant, wide-ranging health marketplace, and allowing patients to choose their therapies within certain limits.

These laws have been formed in a changing context of healthcare in Australia. When the anti-Braund laws were first debated, organised orthodox medicine was close to the height of its professional prominence, cancer care was poorly administered in NSW, and

\footnotetext{
${ }^{108}$ Health Care Complaints Commission, Code of Conduct for Unregistered Health Practitioners (Sydney Health Care Complaints Commission, 2010) NSW Government, 2010, Information for Unregistered Health Practitioners, Health Care Complaints Commission, www.hccc.nsw.gov.au/information/information-forUnregistered-Practitioners/default.aspx (accessed 7 March 2011).

109 Australian Health Ministers' Advisory Council, Consultation Paper: Options for Regulation of Unregistered Health Practitioners (Melbourne: Australian Health Ministers' Advisory Council, 2011), 13-14.

${ }^{110}$ NSW Parliamentary Debates, Legislative Assembly (Sydney, 2006), 28 September.
} 
unorthodox healing lacked a substantial following or organised structure. Thirty years later, many of these contextual features had changed, most especially the prominence and organisation of unorthodox health practices - now an 'industry' of 'complementary and alternative medicine' serving 'consumers'. These changes in the context of healthcare have meant that legislatures have sought to regulate cancer treatment through different components of law at different times, including the Medical Practice Act, Fair Trading and Trade Practices Act and, most recently, the Public Health Act in conjunction with a 'Code of Conduct'. The particular body of law that legislatures have sought to use in regulating cancer treatment and the framing of the law has reflected both the context of healthcare and the NSW legislature's attempts to solve the Sister Kenny problem in different ways.

In recent years, Australia has seen a trend towards harmonising different state laws, including those regulating healthcare. In 2009, NSW and all other states replaced their state-level Medical Practice Acts with a common Health Practitioner Regulation Act. This common act contained only a small component dealing with unregistered practitioners, covering just holding out offences ('title protections') and some restrictions on dental, optical and spinal treatments (Division 10). ${ }^{111}$ However, this year, the Council of Australian Health Ministers is considering a discussion paper on whether a national approach is needed to regulate unregistered practitioners in light of the fact that the Health Practitioner Regulation Act does not cover all CAM and allied health modalities. ${ }^{112}$ The consultation paper specifically considers NSW's approach and one proposal is to replicate that approach in all states or at a national level. ${ }^{113}$ It appears that the legislative ripples from the Braund controversy that this paper has considered may continue to widen.

\footnotetext{
111 Health Practitioner Regulation National Law Act 2009.

112 The legislation covers acupuncturists, Chinese herbal medicine practitioners, chiropractors and osteopaths as well as nurses, occupational therapists, optometrists, dentists, radiographers, pharmacists, physiotherapists, podiatrists, psychologists and all branches of orthodox medical practitioners.

113 Australian Health Ministers' Advisory Council, op. cit. (note 109).
} 